\title{
Measuring the Effect of Service Quality and Corporate Image on Student Satisfaction and Loyalty in Higher Learning Institutes of Technical and Vocational Education and Training
}

\author{
Sallaudin Hassan, Mohd. Farid Shamsudin
}

\begin{abstract}
The 11th Malaysia Plan has emphasized that TVET HLIs is expected to increase the number of enrolment, improve quantity and quality of graduate to meet industry demand. However, in a competitive higher learning industry, previous researches revealed that TVET HLIs are facing challenges such as service quality and corporate image that potentially effect student satisfaction and loyalty. The main objective of this research is to measure the effects of service quality and corporate image on student satisfaction and loyalty. Stimulus- OrganismResponse (SOR) model was adapted in conceptualizing the relationship between the constructs. The scope of study is focus on student from TVET HLIs which is Universiti Kuala Lumpur (UniKL). This study adapted quantitative method whereby questionnaires was used as instrument for data collection. 398 data were collected and analyzed using PLS-SEM. The measurement model indicated that the measurement items are reliable and valid. The structural model indicates that there is a significance and direct effects of service quality and corporate image on student satisfaction and student loyalty. In addition, student satisfaction also has significance and direct effects on student loyalty. In the future research, it is suggest to extend the scope to other TVET HLIs and public HLIs.
\end{abstract}

Index Terms: Service Quality, Corporate Image, Student Satisfaction, Student Loyalty

\section{INTRODUCTION}

Higher Learning Institution (HLIs) in Malaysia is very competitive and the competition is becoming more aggressive with the increasing number of HLIs as to accommodate with the demand for continuing studies at tertiary level. Reference [1] shows that, there are 20 public universities, 36 polytechnics and 478 of privates HLIs in Malaysia. While, according to [2] there are more than 1345 of TVET institutes from various ministries in Malaysia indicating that, TVET HLIs has stiff competition with HLIs under government, privates and within TVET institution itself. Due to stiff competition among the HLIs, ensuring student satisfaction and loyalty is critical for survival in the industry [3].

Through $11^{\text {th }}$ Malaysia Plan (2016-2020), the government highlighted that the number and quality of TVET graduate

Revised Manuscript Received on April 19, 2019.

Sallaudin Hassan. Department of Quality Engineering, Universiti Kuala Lumpur (UniKL), Malaysian Institute of Industrial Technology (MITEC), Bandar Seri Alam, Johor, Malaysia

Mohd. Farid Shamsudin, Department of Marketing, Universiti Kuala Lumpur (UniKL), Business School, Kuala Lumpur, Malaysia. was not meeting demand from industry. Thus, the number student enrolment for TVET HLIs is expected to be increased from 250,000 to 650,000 by 2025 . However, TVET HLIs is facing challenges such as stiff competition with other providers, service quality, image, recognition, fragmented delivery, curriculum and competencies of teaching staff [4]. TVET HLIs as well is seen as unattractive and always been associated with second option. These issues reflects service quality and corporate image of TVET HLIs. Previous research on the linkages between service quality, corporate image, student's satisfaction and student loyalty in TVET HLIs were conducted at separate basis. The research framework was not integrating the four constructs. Research by [5] and [6] on the relationship between service quality, student satisfaction and loyalty suggested that future research to consider other determinant variable of student loyalty. This scenario has created a literature gap where this research is aimed to examine the four constructs and empirically test it in one framework using Partial Least Square- Structural Equation Modelling (PLS-SEM). The research objectives is to determine the effect of service quality on student satisfaction and student loyalty, to determine the effect of corporate image on student satisfaction and student loyalty and to determine the effect of student satisfaction on student loyalty.

\section{LITERATURE REVIEW}

\section{A. Service Quality}

Reference [7] emphasized that perceived service quality by customer will able to determine the level of satisfaction of the customer. In the context of this study, student is the main stakeholder in higher learning institutes (HLIs). Thus, the discussion on service quality in HLIs are emphasized on the service quality from the perspective of student [8]. SERVQUAL is one of the most popular model used in assessing service quality beside SERVPERF, HEdPERF, EduQUAL, SQM-HEI and EDUDSERVE.

The dimension of SERVQUAL has been compressed to five by [9] which is Tangible, Reliability, Responsiveness, Assurance and Empathy. This model has been widely used in various industries such as Tourism [10], Banking [11], 
International Conference on Recents Advancements in Engineering and Technology (ICRAET-18) |15th and 16th March 2019|Siddhartha Institute of Technology \& Sciences, Telangana, India.

Higher Education [12] and transportation [13]. Based on previous studies, service quality is a dominant construct in determining corporate image, customer's satisfaction and loyalty. In the context of TVET HLIs, the following hypotheses are suggested: $H_{1}$ Service quality has significant and direct effect on student satisfaction, $\mathrm{H}_{2}$ Service quality has significant and direct effect on student loyalty.

\section{B. Corporate Image}

Reference [14] emphasized that, image is an overall impression of customer towards the organization based on their feeling and experience. In addition, reference [15] look at image as the distinctive factor for product of service offered by an organization. In addition, reference [16] highlighted that corporate image includes the overall image, institute image and credibility of the institution. Thus, in the context of this study, corporate image term is selected as a construct since it will presents the overall view of student about the image of TVET HLIs. Past studies revealed that there is relationship between corporate image with customer satisfaction [17].In addition, corporate image also influence customer loyalty [18].In the context of TVET HLIs, the following hypotheses are suggested: $\mathrm{H}_{3}$ Corporate image has significant and direct effect on student satisfaction and $\mathrm{H}_{4}$ Corporate image has significant and direct effect on student loyalty.

\section{Student Satisfaction}

Customer satisfaction is defined as a feeling of an individual towards the performance of product or services [19].Reference [20] categorize customer satisfaction to overall satisfaction, technical satisfaction and functional satisfaction. In this study, overall satisfaction is selected as construct. Assessing student satisfaction is critical as it is important as feedback mechanism to the management of organization. Based on feedback, necessary strategies are able to be formulated to lead for improvement. Reference [21] highlighted that in the context of higher learning, it is important for the management of HLIs to continuous improving the teaching aspect and curriculum. Based on past literatures, student satisfaction is prominent construct in determining customer loyalty [22], [23] and [24] Research by [25] revealed that, there is relationship between student satisfaction of administration of college, facilities and faculties with student loyalty. The management of TVET HLIs should consider student satisfaction in developing strategies and organization goal. The following hypotheses is suggested: $H_{5}$ Student satisfaction has significant and direct effect on student loyalty.

\section{Student Loyalty}

Reference [26] defines customer loyalty as a result of developed a good relationship with customer and customer satisfaction. Customer loyalty will result in repeat purchase [27].While, reference [28] emphasized organization to ensure customer satisfaction and loyalty. In the context of HLIs, a loyal student will retain until completion of the study, encourage others and spread positive word of mouth. A loyal student will not quit the university and switch to other university [29].

\section{Conceptual model}

The conceptual model in this study is derived from Stimulus-Organism-Response (SOR) Model [30]. This model depicting a linkages between stimulus (the external factors) which will effect organism (people's cognitive and affective) and reflection of shows by the response of people (behaviour). Stimulus (S) is referred to input which is the external factor. External factors are associated with environment [31].The organism is referred to factors react with the stimuli. Reference [32] highlighted that stimuli involved emotion, feeling and emotion towards the stimuli. Response ( $R$ ) is referred to the action and reaction of customer toward organism. Reference [33] addressed that customer loyalty is a reaction of customer once satisfied with the purchase product or service used. In the context of this study, service quality and corporate is conceptualized as stimulus, satisfaction as organism and student loyalty as response. The conceptual model is depicted in fig. I below.

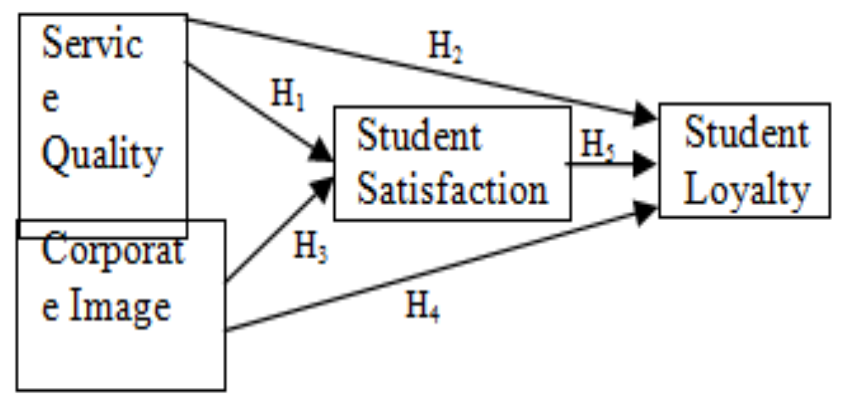

Fig. I: Conceptual framework of relationship between service quality corporate image, student satisfaction and student loyalty.

Based on conceptual model above, the following table summarize the hypotheses in this study.

Table 1.0: Summary of hypothesis

\begin{tabular}{|c|c|}
\hline $0^{N}$ & Hypotheses statements \\
\hline $\mathrm{H}$ & Service quality has significant and direct effect \\
\hline 1 & on student satisfaction, \\
\hline $\mathrm{H}$ & Service quality has significant and direct effect \\
\hline 2 & on student loyalty \\
\hline $\mathrm{H}$ & Corporate image has significant and direct \\
\hline 3 & effect on student satisfaction \\
\hline $\mathrm{H}$ & Corporate image has significant and direct \\
\hline 4 & effect on student loyalty. \\
\hline $\mathrm{H}$ & $\begin{array}{l}\text { Student satisfaction has significant and direct } \\
\text { effect on student loyalty. }\end{array}$ \\
\hline
\end{tabular}

\section{RESEARCH METHOD}

This is a quantitative research whereby survey questionnaire is used for data collection. The questionnaire is categorized to 5 major sections which are Demographic (A), Service Quality (Part B, 31 items), Corporate Image (Part C, 9 items) Student Satisfaction (Part D, 7 items), Student Loyalty (Part E, 6 items). Overall, the questionnaire was developed based on adaptation from past studies by several scholars whereby reliability and validity have been 
tested. However, in this study validity and reliability of the questionnaire are conducted as well.

The scope of study is higher TVET universities which is Universiti Kuala Lumpur (UniKL). The total population in is derived from 10 UniKL campuses that offering technical courses. The total population is 18079. Proportionate stratified sampling was then been used as to determine the sample for each of the selected campuses. Final year student was selected as sample since they have more experience with the university. 431 students were selected as respondent. Prior to data analysis, data screening wad done as to check missing data, wrong code, reverse code, outliers and incomplete data. 398 of good questionnaires were used for data analysis. Data analysis was using SPSS version 21 and Smart PLS 3.0. Normality test was still be conducted as to ensure the data are not too far from normal bell curve. Normality test result shows that the skewness and kurtosis reading meeting the range of -2 and +2 [34].

\section{DISCUSSION OF FINDINGS}

Data analysis for this research is conducted as per guideline by [35]. Two main parts was involve which is measurement model and structural model. In this research, SQ and CI are formative constructs while satisfaction and loyalty are reflective constructs. The measurement model for formative construct for SQ and CI found that Redundancy analysis achieved above threshold 0.7 which is 0.798 and 0.790 respectively. There was no problem of collinearity since the Variance Inflation Factors (VIF) for both SQ and CI below 5. The outer weight and T-value is referred first to determine the indicator's significance level. However, in the case where indicators is not significant, outer loading threshold (above 0.5) is referred before decision is made to retain or remove the indicators. The result showed that some of the indicator achieved $\mathrm{T}$-value less than threshold 1.96 but outer loading more than 0.5 . Thus, all items were retained.

Measurement model for reflective construct (SS and SL) found that the Convergent Validity is passed with loadings more than 0.7 and Average Variance Extracted (AVE) more than 0.5. Both constructs also passed Internal Consistency Reliability where the Composite Reliability and Cronbach's Alpha exceeded 0.6 and 0.7 threshold respectively. The square root of AVE for each Latent Variables (LV) is greater than the correlation among the LVs. In addition, Cross Loading result showed that the outer loading value was greater than its loading with all other remaining constructs.

The structural model result revealed that collinearity for all indicators (VIF values) achieved less than 5. This indicates that there was no collinearity problem. Second, assessing the significance and relevance of the structural model relationships by looking at T-Value (more than 1.96). The result showed that there was a significant and direct relationship of SQ $\rightarrow$ SS (9.493), SQ $\rightarrow$ SL (1.981), and CI $\rightarrow$ SL (8.071). Third, $\mathrm{R}^{2}$ predictive accuracy level for endogenous variable for $\mathrm{CI}$ and $\mathrm{SS}$ was moderate while $\mathrm{R}^{2}$ for SS is high. Fourth, assessment of effect size $\mathrm{f}^{2}$ shows that $\mathrm{SQ} \rightarrow \mathrm{SS}, \mathrm{CI} \rightarrow \mathrm{SS}$ and $\mathrm{SS} \rightarrow \mathrm{SL}$ has medium effect size while SQ $\rightarrow$ SL and CI $\rightarrow$ SL has low effect size. Overall, the structural model assessments are all passed the PLS-
SEM criteria. Fig. II shows the structural model of this study.

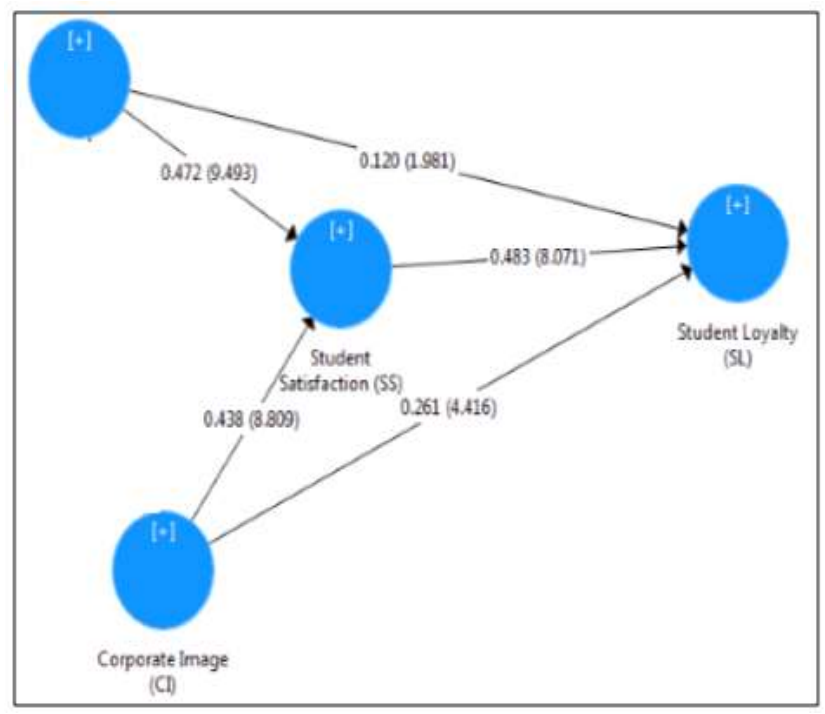

Fig. II: Structural model with bootstrapping.

The bootstrapping result shows that there is direct relationship between all constructs. The highest path coefficient and significant value is the relationship between service quality and corporate image. The $\beta$ and $\mathrm{T}$ value is 0.754 and 32.962 respectively. The lowest path coefficient and significant value is the relationship between service quality and student loyalty. The $\beta$ and $\mathrm{T}$ value is 1.20 and 1.981 respectively. The details bootstrapping 5000 summary shows path coefficient, T- value and $\mathrm{P}$-value as per table 2.0. The relationship between constructs in the structural model significant and relevant is shown. All hypotheses are supported and accepted since the T-value is above 1.96 and $\mathrm{P}$-value is less than 0.05 .

Table 2.0: Hypothesis Test for structural model

\begin{tabular}{|c|c|c|c|c|c|}
\hline \multicolumn{2}{|c|}{ Hypotheses } & \multirow{2}{*}{ 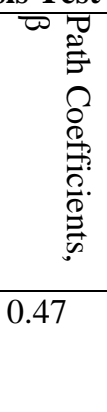 } & \multirow{2}{*}{ 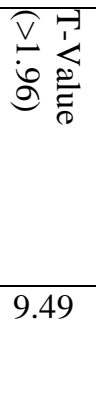 } & \multirow{2}{*}{ 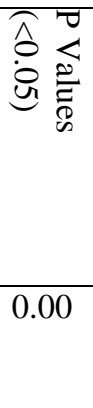 } & \multirow{2}{*}{ 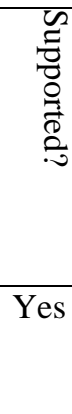 } \\
\hline H1 & $\begin{array}{l}\text { Service Quality -> } \\
\text { Student } \\
\text { Satisfaction }\end{array}$ & & & & \\
\hline $\mathrm{H} 2$ & $\begin{array}{l}\text { Service Quality -> } \\
\text { Student Loyalty }\end{array}$ & 0.12 & 1.98 & 0.04 & Yes \\
\hline H3 & $\begin{array}{l}\text { Corporate Image - } \\
>\quad \text { Student } \\
\text { Satisfaction }\end{array}$ & 0.43 & 8.80 & 0.00 & Yes \\
\hline $\mathrm{H} 4$ & $\begin{array}{l}\text { Corporate Image - } \\
>\text { Student Loyalty }\end{array}$ & 0.21 & 4.41 & 0.00 & Yes \\
\hline H5 & $\begin{array}{l}\text { Student } \\
\text { Satisfaction -> } \\
\text { Student Loyalty }\end{array}$ & 0.48 & 8.07 & 0.00 & Yes \\
\hline
\end{tabular}




\section{DISCUSSION OF FINDING AND CONCLUSION}

Objectives of this study was to measure the effects of service quality and corporate image on student satisfaction and student loyalty in TVET HLIs based on S-O-R model. This study also aim to integrate the four constructs of service quality, corporate image, student's satisfaction and student's loyalty in one framework by using PLS-SEM analysis methodology. This study revealed that service quality has direct and significance effect on student satisfaction. Thus, RQ 1 is addressed and H1 is supported. This finding is consistence with earlier research by [36]. This has confirmed that service quality as stimulus has an effect to satisfaction (organism). Interestingly, this study revealed service quality (stimulus) also has a significant and direct effect with student loyalty (response). This finding is aligned with earlier research conducted by [37]. Based on this finding, it is confirmed that service quality is very dominant construct in determining student satisfaction, student loyalty and corporate image of the TVET HLI. Thus, this research is suggested that the management of TVET HLIs to review the level of service quality.

This research also revealed that corporate image (stimulus) has direct and significant effect on student satisfaction (organism). Interestingly, corporate image (stimulus) as well has direct and significant effect on student loyalty (response). Thus, $\mathrm{RQ}_{4}$ and $\mathrm{RQ}_{5}$ are addressed and $\mathrm{H}_{4}$ and $\mathrm{H}_{5}$ are supported as well. This findings are consistent with previous research by [38].This study has confirmed that corporate image has influence not only on student satisfaction but interestingly it has significant and direct on student loyalty in the context of TVET HLIs. There is no doubt that customer satisfaction is very dominant construct in the relationship with customer loyalty. To sustain in the competitive market, one organization has to ensure customer satisfaction at it has major influence on customer loyalty. This study has confirmed that student satisfaction has direct and significant effect on student loyalty in the context of TVET HLIs. Thus $\mathrm{RQ}_{5}$ is addressed and $\mathrm{H}_{5}$ is supported. This finding is consistent with [39].This research suggest that the management of TVET HLIs to enhance the level of service quality, corporate image and student satisfaction. It is worth to develop student loyalty as they will retain until completion of the study, spread positive word about the university and encourage others to join TVET HLIs. This will help to improve the number of student in TVET HLIs as per expected in the $11^{\text {th }}$ Malaysia Plan

There are limitations in this study. This study underlying assumption that service quality influence satisfaction, corporate image and loyalty. It could be other factors besides service quality that effects student satisfaction, corporate image and student loyalty. Future study is suggested to consider other areas in more details of measuring service quality such as campus environment, physical facilities, training equipment, instructor, curriculum, training delivery, support services, library and management. This study was focus on the relationship between the constructs.It is suggested that the scope of research in the future study to be extended to other TVET and public HLIs as well.
Based on SOR model, it has been shown empirically that, stimuli which is service quality and corporate image affects the student satisfaction which in turn lead to student loyalty. The finding in this study enriching the literature on S-O-R Model. This study contributed to management of TVET HLIs, whereby level of service quality, corporate image, student satisfaction and loyalty is collected and presented. This study established a comprehensive framework and valuable insights into the relationships between service quality, corporate image, student satisfaction and loyalty in TVET HLIs.

\section{REFERENCES}

1. Ministry of Higher Education (2018). Retrieved 20 July, 2018. Available: http://www.mohe.gov.my/en/.

2. Economic Planning Unit \& Prime Minister's Department, 2015. Strategy Paper 9-Transforming Technical and Vocational Education and Training to Meet Industry Demand. Eleventh Malaysia Plan, 20162020

3. Anusorn, K., Duangporn, P. (2015). The mediating effect of satisfaction on student loyalty to higher education institution. European Scientific Journal October 2015 /SPECIAL/ edition 1, ISSN: 1857 - 7881 (Print) e ISSN 1857- 7431

4. Economic Planning Unit (2015). Strategy Paper 9Transforming Technical and Vocational Education and Training to Meet Industry Demand. Eleventh Malaysia Plan, 2016-2020.

5. Subrahmanyam Annamdevula, (2016),"The effects of service quality on student loyalty: the mediating role of student satisfaction", Journal of Modelling in Management, 11(2).

6. Austin, A. J., \& Pervais, S (2017). The Relation Between "Student Loyalty" and "Student Satisfaction" ( A case of College / Intermediate Students at Forman Christian College ), 7881(January), European Scientific Journal January 2017 /SPECIAL/ edition ISSN: 1857 - 7881 (Print) e - ISSN 1857- 743.

7. Cronin, J.J., \& Taylor, S.A. (1992). Measuring service quality: A reexamination and extension. Journal of Marketing, 56(3), 55-68.

8. Gallifa, J., \& Batalle, P. (2010). Student perceptions of service quality in a multi-campus higher education system in Spain. Quality Assurance in Education, 18(2), 156-170.

9. Parasuraman, A., Zeithaml, V. A. and Berry, L. L. (1988), SERVQUAL: A multiple-item scale for measuring consumer perceptions of service quality, Journal of Retailing, 64(1)12-40.

10. Kwok See Ying (2015). The mediation effect of value on experience and service quality towards satisfaction in Malaysian tourism industry. $\mathrm{PhD}$ Thesis. Universiti Teknologi Malaysia.

11. Raza, M. A., Siddiquei, A. N., Awan, H. M., \& Bukhari, K. (2012). Relationship between Service Quality, Perceived Value, Satisfaction and Revisit Intention in Hotel Industry. Interdisciplinary Journal of Contemporary Research In Business, 4(8), 788-805.

12. Fitri HA, Ilias A, Abd Rahman R, Abd Razak MZ (2008) (2008). Service Quality and Student Satisfaction: A Case Study at Private Higher Education Institutions. International Business Research, 1(3), 163-175.

13. Yilmaz, V., \& Ari, E. (2017). The effects of service 
quality, image, and customer satisfaction on customer complaints and loyalty in high-speed rail service in Turkey: a proposal of the structural equation model. Transport Science Journal, 13(1), 67-90.

14. Hatch, M.J., Schultz, M., \& Williamson, J. (2003). Bringing the corporate Into Corporate Branding. European Journal of Marketing, 37(7/8), 104-164.

15. Kotler, P, \& Amstrong (2010). Principles of Marketing, 13edn. Prentice Hall. New Jersey.

16. Kuo, Y.-K., \& Ye, K.-D. (2009). The causal relationship between service quality, corporate image and adults' learning satisfaction and loyalty: A study of professional training programmes in a Taiwanese vocational institute. Total Quality Management \& Business Excellence, 20(7), 749-762.

17. Usman U., \& Mokhtar S.S.M (2016). Analysis of Service Quality, University Image and Student Satisfaction on Student Loyalty in Higher Education in Nigeria. International Business Management. ISSN: 1993-5250.

18. Nguyen, N. \& LeBlanc, G. (2001). Image and Reputation of Higher Education Institutions in Students' Retention Decisions. The International Journal of Educational Management, 15(6/7), 303-311.

19. Kotler, P. (2003). Marketing Management, (11th ed.). Prentice Hall, New Jersey.

20. Abu-EL Samen, A.A., Akroush, M.N., Al-Khawaldeh, F.M. \& Al-Shibly, M.S., 2011, "Towards an integrated model of customer service skills and customer loyalty: The mediating role of customer satisfaction", International Journal of Commerce and Management, 21(4), 349-380.

21. FNair, C. S., Murdoch, N., \& Mertova, P. (2011) Benchmarking the student experience: The offshore campus experience. The TQM Journal, 23(6), 585-597.

22. Kheiry, B. (2012). University intellectual image impact on satisfaction and loyalty of students (Tehran selected universities). African Journal of Business Management, 6(37), 10205-10211.

23. Usman U., \& Mokhtar S.S.M (2016). Analysis of Service Quality, University Image and Student Satisfaction on Student Loyalty in Higher Education in Nigeria. International Business Management. ISSN: 1993-5250.

24. Subrahmanyam Annamdevula, (2016),"The effects of service quality on student loyalty: the mediating role of student satisfaction", Journal of Modelling in Management, 11(2).

25. Austin, A. J., \& Pervais, S (2017). The Relation Between "Student Loyalty" and "Student Satisfaction" ( A case of College / Intermediate Students at Forman Christian College ), 7881(January), European Scientific Journal January 2017 /SPECIAL/ edition ISSN: 1857 - 7881 (Print) e - ISSN 1857- 743.

26. Kotler, P, \& Amstrong, G., Harris C.L., \& Piercy.N., (2017). Principles of Marketing. 7th Edition. Pearson. United Kingdom.

27. Heskett, J. L., Jones, T. O., Loveman, G. W., Sasser Jr., W. E., \& Schlesinger, L. A. (2008). Putting the serviceprofit chain to work. Harvard Business Review, 86(7-8), 118-129

28. Nguyen, N. \& LeBlanc, G. (2001). Image and Reputation of Higher Education Institutions in Students' Retention Decisions. The International Journal of Educational Management, 15(6/7), 303-311.

29. Duque, L.C (2013). A framework analyzing higher education performance: Student's satisfaction, perceived learning outcomes and dropout intentions. Total Quality Management \& Business Excellence Journal, 25:1-2, 121,

30. Mehrabian, A., \& Russell, J. A. (1974). An approach to environmental psychology. Cambridge, MA: M.I.T. Press.
31. Eroglu, S.A., K.A. Machleit, and L.M.Davis. (2001) Atmospheric qualities of online retailing: A conceptual model and implications, Journal of Business Research, 54(2), 177-184.

32. Buxbaum, O. (2016). Key insights into basic mechanisms of mental activity. Key Insights into Basic Mechanisms of Mental Activity, 1-104.

33. Kotler, P, \& Amstrong, G., Harris C.L., \& Piercy.N., (2017). Principles of Marketing. 7th Edition. Pearson. United Kingdom.

34. Kline, R. B. (2005). Principles and Practice of Structural Equation Modeling (2nd ed.): New York: Guilford Press.

35. Hair, J.F., Hult, G.M., Ringle, C.M., and Sarstedlt, M (2017). A primer on partial least squares structural modelling (PLS SEM). USA: Sage Publication, Inc.

36. Meesala, A., \& Paul, J. (2018). Service quality, consumer satisfaction and loyalty in hospitals: Thinking for the future. Journal of Retailing and Consumer Services, 40(July), 261-269.

37. Faizan Ali, Yuan Zhou, Kashif Hussain, Pradeep Kumar, Nair Neethiahnanthan, Ari Ragavan (2016). Does Higher Education Service Quality effect student satisfaction? A study on international student in Malaysia Public University. Quality Assurance in Education, 14(3), 251267.

38. Azoury, N., Daou, L., \& Khoury, C. El. (2014). University image and its relationship to student satisfaction- case of the Middle Eastern private business schools. International Strategic Management Review, 2(1), 1-8.

\section{AUTHORS PROFILE}

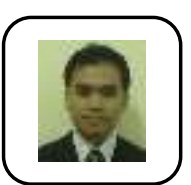

Sallaudin Hassan

Company: University Kuala Lumpur (UniKL), Malaysian Institute of Industrial Technology (MITEC) 81750, Johor Bahru, Johor, Malaysia.

Email: sallaudin@unikl.edu.my

Position: Lecturer.

Education: Master in Management (Technology), UTM, Skudai, Malaysia. PhD Candidate (Universiti Kuala Lumpur, UniKL, Business School, Kuala Lumpur, Malaysia).

Membership: Train the Trainer certified, 2013 (TTT/7736, Malaysian Institute of Management, Chartered Member of CILT (N2187), PRINCE II Certified (Project Management), Chartered Quality Institute (CQI/IRCA 6034614).

Recent Publication List:

1. Education Supply Chain: A case study of Input-Process-Output of High Technical Vocational Education and Training (HTVET), International Journal of Engineering and Technology(UAE) DOI 10.14419/ijet.v7i2.29.13129, 2018

2. Evaluating Critical Success Factors (CSF) and Level of Challenges in Project Life Cycle (PLC). International Journal of Engineering and Technology (UAE).10.14419/ijet.v7i2.29.13131, 2018

3. A proposed framework of relationship between service quality, corporate image, satisfaction and loyalty in higher TVET. Journal of Fundamental and Applied Sciences; ISSN 1112 9867; http://www.jfas.info., 2018

4. Supplier Performance Management at Higher Education Institutes. www. Sciencedirect.com. Elsevier, 2015.

Project List:

1. Voice of customer: a measurement of employer satisfaction towards graduate attributes using quality function deployment approach. (Co researcher, STRG : 2015, Awarded by Universiti Kuala Lumpur).

2. Service Quality in Higher TVET Institutes (Main researcher,STRG : 2017; Awarded by Universiti Kuala Lumpur). 


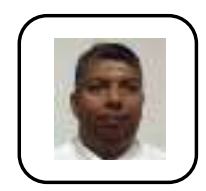

Assoc Prof. Dr. Mohd Farid Shamsudin

Company: University Kuala Lumpur (UniKL), Business School, 54000, Kuala Lumpur Malaysia.

Email: mfarid@unikl.edu.my

Position: Senior Lecturer, Head of Section (Marketing)

Education: Doctorate Business Administration, DBA (Universiti Utara Malaysia), Kedah, Malaysia

\section{Recent Publication List:}

1. Mohd Farid Shamsudin, Khairul Shahida Shabi, Mohamad Noorman Masrek, Hafezali Iqbal Hussain, Milad Abdelnabi Salem, Mohd Faizun Mohamad Yazid. Role of Device Features towards Purchase Intention Using Mobile Commerce. International Journal of Engineering \& Technology, 7 (4.29) (2018) 40-42 (2018).

2. Shamsudin M.F., Nurana N. , Aesya A. , Hussain, H.I. , Milad Abdelnabi Salem, Affendy A.H. The Factors University Location towards Student Choice to Private Universities. International Journal of Engineering \& Technology, 7 (4.29) (2018) 97-99 (2018).

3. Shamsudin, M.F., Khairul Shahida Shabi. , Hussain, H.I., Salem, M.A.. Role of Device Features towards Intention to Use of MCommerce. International Journal of Engineering \& Technology, 7 (4.29) (2018) 100-102 (2018). Hafezali Iqbal Hussain, Mohd Farid Shamsudin, Omar Alaeddin, Abdul Razak Abdul Hadi, Nor Effuandy, fordten Md Saleh, Norhaila Sabli, Noor H Jabarullah. Analysing Shari'ah Compliant Retirement Planning: the Case of Malaysia. International Journal of Engineering \& Technology, 7 (4.29) (2018) 106-111 (2018).

4. H. Sallaudin1,*, S. M. Farid, M. Ishamuddin, S. Athirah1, A Rohaizan1, B. R. Roslan, A. W. M. Ikbar, A. K. Firdaus1, Z. M. Haziq and J. Jimisiah. A Proposed Framework Of Relationship Between Service Quality, Corporate Image, Satisfaction And Loyalty In Higher TVET Universities. Journal of Fundamental and Applied Sciences. ISSN 1112 9867 (2018) 